\title{
Geochemistry of Groundwater in the Uva Province, Sri Lanka-Implications for Chronic Kidney Disease of Uncertain Origin
}

\author{
I. D. U. H. Piyathilake ${ }^{1}$, W. A. C. Udeshani ${ }^{1}$, H. A. C. S. Hapuarachchi ${ }^{2}$, L. V. Ranaweera ${ }^{3}$, \\ E. P. N. Udayakumara ${ }^{3}$, S. K. Gunatilake ${ }^{3 *}$ and Chandra B. Dissanayake ${ }^{4}$ \\ ${ }^{1}$ Faculty of Graduate Studies, Sabaragamuwa University of Sri Lanka, Belihuloya, Sri Lanka, ${ }^{2}$ Department of Sports Sciences \\ and Physical Education, Faculty of Applied Sciences, Sabaragamuwa University of Sri Lanka, Belihuloya, Sri Lanka, \\ ${ }^{3}$ Department of Natural Resources, Faculty of Applied Sciences, Sabaragamuwa University of Sri Lanka, Belihuloya, \\ Sri Lanka, ${ }^{4}$ Department of Geology, Faculty of Science, University of Peradeniya, Peradeniya, Sri Lanka
}

\section{OPEN ACCESS}

Edited by:

Pradeep K. Naik,

Rajiv Gandhi National Ground Water

Training and Research Institute, India

Reviewed by: Ayomi Jayarathne,

The University of Queensland, Australia

Si-Liang Li,

Tianjin University, China

${ }^{*}$ Correspondence:

S. K. Gunatilake

sksg@appsc.sab.ac.lk

Specialty section:

This article was submitted to Water and Human Health

a section of the journal

Frontiers in Water

Received: 06 September 2021 Accepted: 01 November 2021 Published: 09 December 2021

Citation:

Piyathilake IDUH, Udeshani WAC, Hapuarachchi HACS, Ranaweera LV, Udayakumara EPN, Gunatilake SK and Dissanayake CB (2021) Geochemistry of Groundwater in the Uva Province, Sri Lanka-Implications

for Chronic Kidney Disease of Uncertain Origin

Front. Water 3:771501.

doi: 10.3389/frwa.2021.771501
The prevalence of chronic kidney disease of uncertain etiology (CKDu) in the Uva Province (UP) of Sri Lanka has received much attention over the past two decades. Many scientists assumed that prolonged consumption of drinking water with high levels of contaminants may be the causative factor. Thus, the prime objective of this study is to develop a binary logistic regression model based on water quality parameters and the prevalence of CKDu to find out the geochemical risk factors that affect the CKDu. For this, 260 groundwater samples were collected following a stratified random sampling method and analyzed for its major cations, anions, and selected trace element contents. In the model, the dichotomous dependent variable defines the availability of CKDu patients, and explanatory variables define groundwater quality parameters. According to the best-fit model, $\mathrm{F}^{-}$and $\mathrm{PO}_{4}^{3-}$ levels of the groundwater were found to be the geochemical risk factors that were significantly associated with the progression of CKDu in the study area. Furthermore, it was shown that geochemical processes such as dissolution of bedrocks are the causative phenomenon of the enhancement of $\mathrm{F}^{-}$levels in the groundwater sources. It has also been observed that the $\mathrm{PO}_{4}^{3-}$ concentrations of the groundwater possibly increase because of the intensive application of agrochemicals in addition to geogenic sources. The results of this study can be used by the government authorities in groundwater management and the management of the prevalence of CKDu disease in the study area. Furthermore, the findings of this study will contribute to the policy-makers in Sri Lanka for providing safe drinking water to meet the sustainable development goals (SDGs).

Keywords: CKDu, fluoride, groundwater, binary logistic regression, phosphate

\section{INTRODUCTION}

Chronic kidney disease (CKD) is a global health crisis (Noble et al., 2014; Wimalawansa, 2016; Wu and $\mathrm{Wu}, 2019$ ) because the kidney-related disease had been recognized as the 12th most common disease that causes death and the 17th most common disease that causes disability (Murray et al., 2001; Jayasekara et al., 2015). Diabetes mellitus, glomerulonephritis, and long-term hypertension 
have resulted in the prevalence of CKD in most cases (Kumaresan and Seneviratne, 2017). However, a particular form of CKD had emerged in the mid-1990s, in which the etiology does not link to the commonly known risk factors, viz., diabetes mellitus, glomerulonephritis, and hypertension (Jayatilake et al., 2013; Jayasumana et al., 2015). The reason for these CKD cases reported in Sri Lanka had not been clearly defined as yet, and thus, the term CKD of unknown/uncertain etiology $(\mathrm{CKDu})$ is used (Bandara et al., 2010; Wanigasuriya, 2012; Jayasumana et al., 2013; Noble et al., 2014). However, CKDu has become one of the most serious health problems and is increasing at an alarming frequency at present in Sri Lanka (Wimalawansa, 2016; Wanasinghe et al., 2018). As explained by Jayasumana et al. (2013), the first case of CKDu in Sri Lanka was reported in the Padaviya farming area in the North Central Province (NCP). In Sri Lanka, the dry zone farming areas, viz., NCP, Uva Province (UP), Central Province (CP), North Western Province (NWP), and Eastern Province (EP), are the most affected provinces with $\mathrm{CKDu}$, whereas Medawachchiya and Medirigiriya in NCP, Girandurukotte and Mahiyanganaya in UP, Dehiattakandiya in EP, and Wilgamuwa and Hettipola in $\mathrm{CP}$ are the most prominent $\mathrm{CKDu}$-distributed areas in Sri Lanka (Figure 1A). Moreover, as explained by Wanasinghe et al. (2018), the pattern of distribution of CKDu has spread outside the NCP, and it is now prevalent in the UP. As explained by Abeysekara (2015), UP has been identified as one of the most prominent provinces that progressively show an increase in the number of patients with $\mathrm{CKDu}$, and according to the official estimates, over 15,000 of patients with CKDu and over 4,500 deaths were recorded from Mahiyanganaya, Girandurukotte, Central Hettipola, Bakamuna, and Eastern Dehiatta of UP by the end of 2015. Thus, it has a direct impact on the daily life of patients. This includes their livelihood activities, and it indirectly affects them financially, socially, and psychologically, whereas almost $80 \%$ of these patients eventually die from kidney failure within the first 2 years after diagnosis (Gunatilake et al., 2014). Therefore, the determination of possible risk factors associated with $\mathrm{CKDu}$ is vital to control the prevalence of the disease.

As explained by Dissanayake and Chandrajith (2017), the people of the $\mathrm{CKDu}$-vulnerable areas consume groundwater as their primary drinking water source, and hence, they suffer from marked dehydration under hot and humid conditions. Furthermore, it is assumed that $\mathrm{CKDu}$ is directly related to the quality of drinking water (Athuraliya et al., 2009; Abeysekara, 2015; Fernando et al., 2016). According to the previous studies, $\mathrm{CKDu}$ is caused by combined multifactor, making it difficult to recognize individual risk factors and possible interactions linked to the disease (Wanigasuriya, 2014; Levine et al., 2016). In Sri Lanka, many scientists assumed and proposed that prolonged consumption of drinking water with high levels of contaminants, notably fluoride $\left(\mathrm{F}^{-}\right)$(Dissanayake, 2005; Ileperuma et al., 2009), cadmium (Cd) (Bandara et al., 2008; Wanigasuriya et al., 2011), arsenic (As) (Jayasumana et al., 2013), and agrochemical residues like glyphosate (Jayasumana et al., 2013), is the root cause for the progression of the CKDu. Furthermore, Dissanayake (2005) first suggested that prolonged consumption of groundwater with high $\mathrm{F}^{-}$content and the interaction of $\mathrm{F}^{-}$with other elements could be a possible risk factor for the progression of CKDu in dry zones of Sri Lanka. This has been confirmed by the development of spatial distribution of $\mathrm{F}^{-}$map for the entire country by Chandrajith et al. (2012) because the spatial distribution of CKDu coincided well with that of the $\mathrm{F}^{-}$rich regions in Sri Lanka. Moreover, Dissanayake and Chandrajith (2017) further explained that the effects of $\mathrm{F}^{-}$and water hardness could well be a risk factor in the etiology of CKDu.

Although many types of epidemiological cross-sectional studies have been carried out to find the root cause for CKDu in Sri Lanka, UP in its entirety had been neglected to some extent. It was also observed that no single geochemical parameter could be directly related to the CKDu etiology (Athuraliya et al., 2011; Wanigasuriya et al., 2011; Jayatilake et al., 2013). Thus, the prime objective of this study is to identify the major geochemical risk factors associated with the CKDu in the UP of Sri Lanka by applying advanced statistical approaches. In recent years, many countries are experiencing water stress due to the lack of safe and affordable drinking water. It is projected that at least one in four people will suffer recurring water shortages in 2050. Under the United Nations sustainable development goals (SDGs), ensuring safe and affordable drinking water by 2030 is one of the important considerations. Therefore, the findings of the study can be effectively used by the relevant government organizations in the prevalence of the CKDu disease in Sri Lanka, and the findings of this study will contribute to the policy-makers in Sri Lanka for proper management of groundwater resources and provision of safe drinking water to meet the SDGs.

\section{MATERIALS AND METHODS}

\section{Study Area}

The UP is located in the southeast part of Sri Lanka, and it lies between longitudes $80^{\circ} 40^{\prime} 0^{\prime \prime} \mathrm{E}$ to $80^{\circ} 41^{\prime} 0^{\prime \prime} \mathrm{E}$ and latitudes $6^{\circ} 20^{\prime} 0^{\prime \prime} \mathrm{N}$ to $7^{\circ} 40^{\prime} 0^{\prime \prime} \mathrm{N}$ with an area of about $8,500 \mathrm{~km}^{2}$ (Figure 1B). The study area is mainly bordered by Eastern, Southern, Sabaragamuwa, and CPs (UPC, 2019). Uva Province consists of two main administrative districts, namely, Badulla and Monaragala. The total land area of the Badulla district is 2,861 $\mathrm{km}^{2}$ and that of the Monaragala District is $5,639 \mathrm{~km}^{2}$.

\section{Topography, Geology, and Soil}

The physical landscape of the Badulla district consists of mountain ranges, divided plateaus, and narrow valleys. Geologically, the Badulla district is located toward the East of the Central Highland complex, whereas the Monaragala district is located in a transition zone within central highlands to flat terrain. The latter consists of various terrain types, viz., hill-steep highly mountainous terrain and flat terrain. The prominent soil types of the Badulla district include Red Earth and Brown Loams, Red-Yellow Padzolic, and Reddish Brown soils, whereas major soil types of the Monaragala district are Reddish Brown Earth and Red Yellow Padzolic soils (RDA, 2017).

\section{Climate}

The average annual rainfall in the Badulla district varies from 1,800 to more than $2,500 \mathrm{~mm}$. Rainfall is received during four 

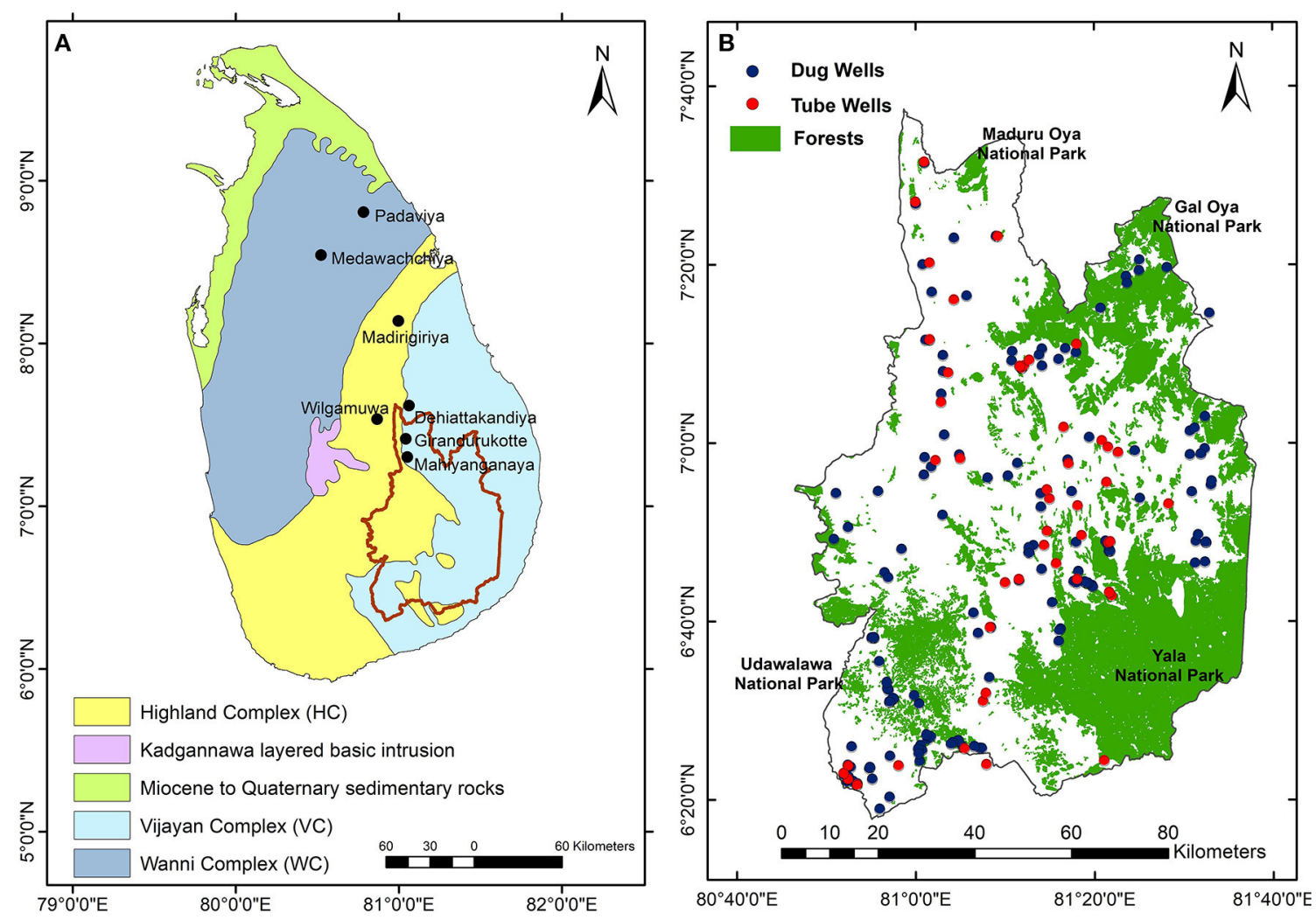

FIGURE 1 | (A) Map showing the simplified lithotectonic map of Sri Lanka (modified after Cooray, 1994) with high CKDu prevalence areas. (B) The groundwater sampling locations of the study area. Source of the forest layer: Survey Department of Sri Lanka (2018).

seasons, namely, first inter-monsoon (March to April), Southwest Monsoon (July to September), second inter-monsoon (October to November), and Northeast monsoon (December to January). In addition, the average annual temperature of the district varies between 16 and $30^{\circ} \mathrm{C}$. The average annual rainfall in the Monaragala district ranges from 1,300 to $1,800 \mathrm{~mm}$, and the two rainy seasons extend from early October to late January and from late March to late May, respectively. The annual temperature of the Monaragala district varies from 21.6 to $35^{\circ} \mathrm{C}$ (RDA, 2017).

\section{Ecological Environment}

The total extent of the land under protection in the UP exceeds $2,000 \mathrm{~km}^{2}$. The forest cover mainly comprises montane, submontane tropical, dry, evergreen, and mixed forests. In addition, important wildlife areas within the district include Gal Oya National Park, Yala National Park, Udawalawa National Park, and Maduru Oya National Park. The considerable land area of the province covers mainly forest areas (31.4\%), scrublands $(22.12 \%)$, home gardens $(14.78 \%)$, rice $(20.9 \%)$, and Chena cultivation for short-term crops (10.72\%) (Piyathilake et al., 2021).

\section{Sampling Procedure}

The groundwater sampling program was designed following the stratified random sampling procedure. The entire study area was divided into $100 \mathrm{~km}^{2}$ grids, and 260 groundwater samples were collected from January 2020 to March 2021 covering 1year period. Groundwater samples were collected according to the availability from each grid by applying standard methods for sample collection and preservation. Groundwater samples were collected from 174 dug wells, in which the average depth is $\sim 10$ feet and 86 tube wells in which the depth ranged from 30 to 80 feet. The sampling process has been carried out covering the whole of UP, whereas the Geographical Positioning System (GPS) coordinates of the locations were recorded by using a MAGELLAN ${ }^{\mathrm{TM}}$ GPS receiver. Groundwater samples were collected into properly labeled high-density polyethylene bottles that were acid-soaked overnight and then washed thoroughly with deionized water and oven-dried for $3 \mathrm{~h}$ at $50^{\circ} \mathrm{C}$. Before collecting samples, bottles were rinsed several times with the same water to be sampled. Two subsets of samples were collected for laboratory analysis, in which one was filtered and acidified by adding several drops of concentrated nitric acid $(\mathrm{pH}<2)$ for cation analysis, whereas the unacidified sample was used for anion analysis. All samples were kept cool during transportation to the laboratory. Furthermore, at each groundwater sampling point, the availability of patients with CKDu who had consumed the drinking water from the source was recorded. Accordingly, $\sim 33 \%$ of dug wells and $\sim 28 \%$ of tube wells were identified as groundwater sources where patients with $\mathrm{CKDu}$ had been consuming water for drinking purposes. The sampling points 
were plotted by using ArcMap ${ }^{\mathrm{TM}} 10.4$ mapping software to be used in data analysis (Figure 1B).

\section{Chemical Analysis}

Field measurements of water quality parameters (temperature, $\mathrm{pH}$, and electrical conductivity) of collected groundwater samples were recorded using a pre-calibrated Thermo Scientific Orion Star A325 ${ }^{\mathrm{TM}}$ Multiparameter test kit. All other chemical parameters were determined using standard procedures described by the American Public Health Association (APHA, 2005). The total alkalinity, total hardness, and chloride $\left(\mathrm{Cl}^{-}\right)$of the samples were analyzed using a $\mathrm{Hach}^{\mathrm{TM}}$ digital titrator. To measure alkalinity, the sulfuric acid method was used, whereas the ethylenediaminetetraacetic acid (EDTA) and silver nitrate methods were used, respectively, for the analysis of total hardness and chloride. Nitrate $\left(\mathrm{NO}_{3}^{-}\right)$, sulfate $\left(\mathrm{SO}_{4}^{2-}\right)$, phosphate $\left(\mathrm{PO}_{4}^{3-}\right)$, and fluoride $\left(\mathrm{F}^{-}\right)$contents were determined using a Hach ${ }^{\mathrm{TM}} \mathrm{DR}$ 2700 spectrophotometer. Major cations [sodium ( Na), potassium $(\mathrm{K})$, calcium $(\mathrm{Ca})$, and magnesium $(\mathrm{Mg})]$ were measured using atomic absorption spectrophotometry (Varian 240FS) at the Sabaragamuwa University of Sri Lanka, whereas trace metals [aluminum (Al), chromium (Cr), manganese $(\mathrm{Mn})$, iron $(\mathrm{Fe})$, cobalt $(\mathrm{Co})$, nickel $(\mathrm{Ni})$, copper $(\mathrm{Cu})$, zinc $(\mathrm{Zn})$, arsenic (As), cadmium $(\mathrm{Cd})$, and lead $(\mathrm{Pb})$ ] were measured by inductively coupled plasma mass spectrometry (Thermo iCAP Q) at the University of Peradeniya, Sri Lanka.

\section{Variable Specification and Working Hypothesis}

In this study, a dichotomous dependent variable $(Y)$ was defined, which signifies the availability of patients with $\mathrm{CKDu}$ who had consumed the groundwater of a particular groundwater source, where $Y=1$, if CKDu patient is available, and $Y=0$, otherwise. The selected independent geochemical variables of the study were hypothesized to be associated with the prevalence of $\mathrm{CKDu}$ disease in the UP. On the basis of the findings from previous studies, 17 explanatory variables were selected to structure the working hypotheses. The potential explanatory variables, which were hypothesized to influence the prevalence of the $\mathrm{CKDu}$ in the study area, are briefly described in Table 1. The effects of trace heavy metals were omitted because their contents in the samples were below the permissible limits recommended by the SLS 614:2013 (Sri Lankan Standard) for drinking purposes.

\section{Model Specification}

As explained by Coutinho et al. (2008), cross-sectional studies are defined as studies with individual-level variables that measure exposure and disease at one point in time, and these study designs provide evidence of the causal association between exposure and outcome. In most epidemiological cross-sectional studies, binary logistic model has been applied (Martuzzi and Elliott, 1998; de Queiroz Mello et al., 2006; Diaz-Quijano, 2012). The binary logistic regression procedure is a popular statistical method (Kleinbaum et al., 2002), wherein the probability of a dichotomous result (such as CKDu patient or non-patient) is related to a set of explanatory variables that are hypothesized to influence the result. In this study, the logistic model
TABLE 1 | Description of explanatory variables.

\begin{tabular}{llll}
\hline Variable & Description & Unit & Variable type \\
\hline$X_{1}$ & $\mathrm{pH}$ & - & Continuous \\
$X_{2}$ & Electrical conductivity $(\mathrm{EC})$ & $\mathrm{\mu S} / \mathrm{cm}$ & Continuous \\
$X_{3}$ & Resistivity (Res) & $\Omega$ & Continuous \\
$X_{4}$ & Total dissolved solids (TDS) & $\mathrm{mg} / \mathrm{L}$ & Continuous \\
$X_{5}$ & Salt $(\mathrm{NaCl})$ & $\mathrm{mg} / \mathrm{L}$ & Continuous \\
$X_{6}$ & Dissolved oxygen $(\mathrm{DO})$ & $\mathrm{mg} / \mathrm{L}$ & Continuous \\
$X_{7}$ & Total hardness & $\mathrm{mg} / \mathrm{L}$ & Continuous \\
$X_{8}$ & Bicarbonate $\left(\mathrm{HCO}_{3}^{-}\right)$ & $\mathrm{mg} / \mathrm{L}$ & Continuous \\
$X_{9}$ & Chloride $\left(\mathrm{Cl}^{-}\right)$ & $\mathrm{mg} / \mathrm{L}$ & Continuous \\
$X_{10}$ & Fluoride $\left(\mathrm{F}^{-}\right)$ & $\mathrm{mg} / \mathrm{L}$ & Continuous \\
$X_{11}$ & Nitrate $\left(\mathrm{NO}_{3}^{-}\right)$ & $\mathrm{mg} / \mathrm{L}$ & Continuous \\
$X_{12}$ & Phosphate $\left(\mathrm{PO}_{4}^{3-}\right)$ & $\mathrm{mg} / \mathrm{L}$ & Continuous \\
$X_{13}$ & Sulfate $\left(\mathrm{SO}_{4}^{2-}\right)$ & $\mathrm{mg} / \mathrm{L}$ & Continuous \\
$X_{14}$ & Sodium $(\mathrm{Na})$ & $\mathrm{mg} / \mathrm{L}$ & Continuous \\
$X_{15}$ & Magnesium $(\mathrm{Mg})$ & $\mathrm{mg} / \mathrm{L}$ & Continuous \\
$X_{16}$ & Potassium $(\mathrm{K})$ & $\mathrm{mg} / \mathrm{L}$ & Continuous \\
$X_{17}$ & Calcium $(\mathrm{Ca})$ & $\mathrm{mg} / \mathrm{L}$ & Continuous \\
\hline
\end{tabular}

characterizing the $\mathrm{CKDu}$ prevalence measures by the sample groundwater source is specified in Equation (1).

$$
\ln \left[\frac{P_{i}}{1-P_{i}}\right]=\beta_{0}+\beta_{1} X_{1 i}+\beta_{2} X_{2 i}+\ldots+\beta_{k} X_{k i}
$$

where

$i=i^{\text {th }}$ observation in the sample;

$P_{i}=$ probability of the outcome;

$\beta_{0}=$ intercept;

$\beta_{1}, \beta_{2,} \ldots, \beta_{k}=$ coefficients associated with each explanatory variable $X_{1}, X_{2}, . ., X_{k}$.

RStudio version 1.4 statistical package was used to analyze the data. At the start, the above mentioned 17 covariates were used for the bivariate correlation analysis. The dichotomous dependent variable, the availability of patients with CKDu who had been consumed the groundwater source $(1=$ yes and $0=$ no), was considered to fit the binary logistic regression model with the mentioned 17 explanatory variables. The stepwise model selection procedure was used to select the best fit model that identifies the significant geochemical risk factors that influence the prevalence of $\mathrm{CKDu}$.

\section{RESULTS AND DISCUSSION}

Previous studies revealed that CKDu is caused by combined multifactors, making it difficult to recognize individual risk factors and possible interactions linked to the disease (Wanigasuriya, 2014; Levine et al., 2016). Many geochemical studies (Wanigasuriya et al., 2007; Athuraliya et al., 2009; Jayasumana et al., 2015; Fernando et al., 2016; Rajapakshe et al., 2018; Pry et al., 2019) have been focused on finding the causative root factors affecting $\mathrm{CKDu}$ especially in the dry zone of the country. Because of the lack of such research conducted in UP 
TABLE 2 | Descriptive statistics of the water quality parameters of the study area.

\begin{tabular}{|c|c|c|c|c|c|c|c|}
\hline \multirow[t]{2}{*}{ Variable } & \multirow[t]{2}{*}{ Unit } & \multicolumn{2}{|c|}{ All wells } & \multicolumn{2}{|c|}{ Dug wells } & \multicolumn{2}{|c|}{ Tube wells } \\
\hline & & Mean & St. dev. & Mean & St. dev. & Mean & St. dev. \\
\hline $\mathrm{pH}$ & - & 7.04 & 0.50 & 7.17 & 1.55 & 7.00 & 0.44 \\
\hline EC & $\mu \mathrm{S} / \mathrm{cm}$ & 724.20 & 620.70 & 687.93 & 662.85 & 797.51 & 521.26 \\
\hline TDS & $\mathrm{mg} / \mathrm{L}$ & 588.62 & 537.09 & 571.01 & 590.45 & 624.22 & 409.24 \\
\hline Nitrate & $\mathrm{mg} / \mathrm{L}$ & 2.80 & 1.57 & 2.78 & 1.55 & 2.83 & 1.58 \\
\hline Phosphate & $\mathrm{mg} / \mathrm{L}$ & 0.68 & 0.86 & 0.69 & 0.84 & 0.63 & 0.91 \\
\hline Sulfate & $\mathrm{mg} / \mathrm{L}$ & 33 & 52 & 31 & 53 & 35 & 48 \\
\hline Fluoride & $\mathrm{mg} / \mathrm{L}$ & 0.98 & 0.83 & 0.93 & 0.80 & 1.08 & 0.88 \\
\hline Chloride & $\mathrm{mg} / \mathrm{L}$ & 60.21 & 92.15 & 61.42 & 104.73 & 57.62 & 59.42 \\
\hline Bicarbonate & $\mathrm{mg} / \mathrm{L}$ & 262.6 & 166.5 & 246.50 & 175.50 & 284.35 & 143.50 \\
\hline Hardness & $\mathrm{mg} / \mathrm{L}$ & 234 & 170 & 222 & 179 & 258 & 145 \\
\hline Sodium & $\mathrm{mg} / \mathrm{L}$ & 66.26 & 84.65 & 62.10 & 86.55 & 74.66 & 80.48 \\
\hline Magnesium & $\mathrm{mg} / \mathrm{L}$ & 23.05 & 29.60 & 20.19 & 27.85 & 28.84 & 32.25 \\
\hline Potassium & $\mathrm{mg} / \mathrm{L}$ & 2.11 & 1.83 & 1.85 & 1.79 & 2.61 & 1.78 \\
\hline Calcium & $\mathrm{mg} / \mathrm{L}$ & 56.01 & 36.65 & 53.82 & 35.30 & 60.41 & 39.05 \\
\hline Aluminum & $\mu g / L$ & 20.98 & 46.40 & 24.26 & 54.59 & 14.48 & 21.81 \\
\hline Chromium & $\mu \mathrm{g} / \mathrm{L}$ & 0.65 & 1.37 & 0.70 & 1.63 & 0.56 & 0.57 \\
\hline Manganese & $\mu \mathrm{g} / \mathrm{L}$ & 68.90 & 150.30 & 73.59 & 176.46 & 59.62 & 79.03 \\
\hline Iron & $\mu g / L$ & 481.30 & 912.00 & 417.26 & 967.08 & 608.01 & 785.25 \\
\hline Cobalt & $\mu g / L$ & 0.54 & 1.16 & 0.57 & 1.36 & 0.47 & 0.52 \\
\hline Nickel & $\mu \mathrm{g} / \mathrm{L}$ & 4.58 & 5.50 & 3.98 & 4.09 & 5.77 & 7.45 \\
\hline Copper & $\mu \mathrm{g} / \mathrm{L}$ & 11.39 & 44.33 & 1.89 & 2.29 & 30.19 & 73.34 \\
\hline Zinc & $\mu \mathrm{g} / \mathrm{L}$ & 42.54 & 87.43 & 26.62 & 35.63 & 74.06 & 137.92 \\
\hline Arsenic & $\mu \mathrm{g} / \mathrm{L}$ & 0.52 & 0.95 & 0.52 & 0.85 & 0.52 & 1.12 \\
\hline Cadmium & $\mu \mathrm{g} / \mathrm{L}$ & 0.18 & 0.12 & 0.17 & 0.11 & 0.20 & 0.13 \\
\hline Lead & $\mu \mathrm{g} / \mathrm{L}$ & 1.37 & 4.16 & 0.76 & 2.29 & 2.5 & 6.2 \\
\hline
\end{tabular}

$B D L$, below detection limit.

and because patients with $\mathrm{CKDu}$ are rapidly increasing within UP, it was an urgent need to study and identify the root causes of CKDu using an advanced statistical approach to prevent and treat the disease as well as save vulnerable lives in the study region.

\section{Descriptive Characteristics of Groundwater Quality Parameters}

Individual determination of the groundwater quality parameters is essential to identify the effects of those parameters on the prevalence of $\mathrm{CKDu}$ in the study area. Thus, the physicochemical parameters including its descriptive statistical measures are reported in Table 2 . The $\mathrm{pH}$ is one of the most important water quality parameters, which determines the acidity or alkalinity of the groundwater, $\mathrm{pH} 7$ in the groundwater at $25^{\circ} \mathrm{C}$ being considered neutral (Nelson, 2002). However, pH values of the groundwater in the study area vary between 5.04 and 8.87 , whereas the mean $\mathrm{pH}$ of the study area was recorded as $7.04 \pm 0.50$. In $\mathrm{CKDu}$ wells, $\sim 8 \%$ of the dug wells samples and $\sim 5 \%$ of tube wells samples were recorded as slightly acidic ( $<6.5$ ), whereas in non-CKDu wells, $\sim 11 \%$ of dug wells, and $\sim 15 \%$ of tube wells were recorded as slightly acidic. The electrical conductivity (EC) and total dissolved solids (TDS) in the groundwater are measurements of the dissolved constituents in an aqueous solution. This means that, when the TDS increases, the EC also increases, and vice versa. As shown in Table 2, the mean EC values of the groundwater in the study area were recorded as $724.2 \pm 620.7 \mu \mathrm{S} / \mathrm{cm}$, whereas the mean value of TDS was recorded as $588.62 \pm 537.09 \mu \mathrm{S} / \mathrm{cm}$. The results revealed that all the groundwater samples from both dug wells and tube wells ranged below the maximum permissible level $(3,500 \mu \mathrm{S} / \mathrm{cm})$. Nitrate $\left(\mathrm{NO}_{3}^{-}\right)$and phosphate $\left(\mathrm{PO}_{4}^{3-}\right)$ are also significant water quality parameters in the study area because the majority of people in the study area engage in fertilizer application (Gunatilake and Iwao, 2009, 2010; Piyathilake et al., 2020). However, the $\mathrm{NO}_{3}^{-}$(as $\mathrm{NO}_{3}^{-}-\mathrm{N}$ ) concentration of the groundwater in the study area ranged from 0.12 to $11.51 \mathrm{mg} / \mathrm{L}$ with the mean value of $2.79 \pm 1.56 \mathrm{mg} / \mathrm{L}$. In CKDu wells, $\sim 2 \%$ of the dug wells samples and $\sim 5 \%$ of tube wells samples were unsuitable for drinking purposes $(>10 \mathrm{mg} / \mathrm{L})$, whereas in non-CKDu wells, only $\sim 1 \%$ of dug wells and none of the tube wells were unsuitable for drinking purposes in terms of $\mathrm{NO}_{3}^{-}$ concentrations according to Sri Lanka Standards for potable water (SLS 614:2013). In collected groundwater samples, $\mathrm{PO}_{4}^{3-}$ concentrations ranged between 0.02 and $5.86 \mathrm{mg} / \mathrm{L}$ with the mean value of $0.67 \pm 0.86 \mathrm{mg} / \mathrm{L}$. In CKDu wells, $\sim 9 \%$ of the dug 
wells samples and $\sim 21 \%$ of tube wells samples were unsuitable for drinking purposes $(>2 \mathrm{mg} / \mathrm{L})$, whereas in non-CKDu wells, only $\sim 2 \%$ of dug wells and none of the tube wells were unsuitable for drinking purposes in terms of $\mathrm{PO}_{4}^{3-}$ concentrations according to SLS 614:2013. As explained by Ketata et al. (2012), $\mathrm{NO}_{3}^{-}$is the ultimate product of aerobic stabilization of organic nitrogen, which is recognized as an indicator of water pollution. As explained by Murphy and Riley (1962), although the transport of inorganic $\mathrm{PO}_{4}^{3-}$ is relatively possible in soils with rich organic matter, the contamination of groundwater by the $\mathrm{PO}_{4}^{3-}$ application in agricultural activities is low. This means that only the dissolved $\mathrm{PO}_{4}^{3-}$ can be present in the groundwater, which can filter through 0.45 -micron filters, this fraction of the $\mathrm{PO}_{4}^{3-}$ being termed orthophosphate (Steenvoorden, 1976). $\mathrm{SO}_{4}^{2-}$ in groundwater is mostly available due to the dissolution of rocks, which contain compounds, viz., gypsum, iron sulfides, and other sulfur-containing materials (Chaurasia et al., 2018). As revealed by the results of this study, the values of $\mathrm{SO}_{4}^{2-}$ concentrations ranged from below detection limit to $540 \mathrm{mg} / \mathrm{L}$ with the mean $\mathrm{SO}_{4}^{2-}$ concentration of $33 \pm 52 \mathrm{mg} / \mathrm{L}$. However, none of the samples from both dug wells and tube wells exceeded the maximum permissible limit $(250 \mathrm{mg} / \mathrm{L})$ of $\mathrm{SO}_{4}^{2-}$ in drinking water according to SLS 614: 2013. In addition, the mean $\mathrm{F}^{-}$ concentration of groundwater in the study area was recorded as $0.97 \pm 0.83 \mathrm{mg} / \mathrm{L}$, which ranged from below detection limit to $5.65 \mathrm{mg} / \mathrm{L}$. The mechanism of leaching of $\mathrm{F}^{-}$into groundwater has been clearly explained by Chandrajith et al. (2012), and according to the explanation, intense weathering of rocks and minerals enhances the entry of $\mathrm{F}^{-}$into the groundwater and is therefore leached out from the F-bearing minerals. However, in CKDu wells, $\sim 48 \%$ of the dug wells samples and $\sim 42 \%$ of tube wells samples were unsuitable for drinking purposes $(>2 \mathrm{mg} / \mathrm{L})$, whereas in non-CKDu wells, only $\sim 23 \%$ of dug wells and $\sim 21 \%$ of tube wells were unsuitable for drinking purposes in terms of $\mathrm{F}^{-}$concentrations. $\mathrm{Cl}^{-}$is also considered as one of the most important water quality parameters because higher levels of $\mathrm{Cl}^{-}$ may cause severe health effects in human beings (Pius et al., 2012). In the analyzed groundwater samples, $\mathrm{Cl}^{-}$was recorded as the mean value of $60.21 \pm 992.15 \mathrm{mg} / \mathrm{L}$ with the minimum and maximum values of 7.00 and $1100.00 \mathrm{mg} / \mathrm{L}$, respectively. However, none of the samples from both dug wells and tube wells exceeded the maximum permissible limit $(250 \mathrm{mg} / \mathrm{L}$, SLS 614:2013) of $\mathrm{Cl}^{-}$in drinking water. The $\mathrm{HCO}_{3}^{-}$alkalinity of the samples ranged between 12.0 and $820.0 \mathrm{mg} / \mathrm{L}$ with a mean value of $262.6 \pm 166.5 \mathrm{mg} / \mathrm{L}$. As explained by Chaurasia et al. (2018), $\mathrm{HCO}_{3}^{-}$may enter groundwater because the action of carbon dioxide in the water on carbonated rocks, viz., dolomite and limestone. The hardness of the groundwater is also considered an important factor that determines the groundwater quality for drinking purposes. As explained by Ravikumar et al. (2011), $\mathrm{Ca}, \mathrm{Mg}, \mathrm{SO}_{4}^{2-}, \mathrm{Cl}^{-}, \mathrm{CO}_{3}^{2-}$, and $\mathrm{HCO}_{3}^{-}$of the water may cause water hardness. However, in this study, the mean hardness of the groundwater was recorded as $234.4 \pm 169.7 \mathrm{mg} / \mathrm{L}$, and the hardness values ranged between 4 and 1,464 mg/L. However, in CKDu wells, $\sim 25 \%$ of the dug wells samples and $\sim 36 \%$ of tube wells samples were unsuitable for drinking purposes $(>300$ $\mathrm{mg} / \mathrm{L}$, SLS 614:2013), whereas in non-CKDu wells, only $\sim 23 \%$ of dug wells and $\sim 17 \%$ of tube wells were unsuitable for drinking purposes in terms of hardness.

The major cation trend in the groundwater of the UP is $\mathrm{Na}^{+}>\mathrm{Ca}^{2+}>\mathrm{Mg}^{2+}>\mathrm{K}^{+} . \mathrm{Na}$ is the dominant cation and the levels of sodium ranged between 0.17 and $608.74 \mathrm{mg} / \mathrm{L}$ with a mean value of $66.26 \pm 84.65 \mathrm{mg} / \mathrm{L}$. $\mathrm{Ca}^{2+}$ is the second dominant cation in the study area, which shows a mean value of 56.01 $\pm 36.65 \mathrm{mg} / \mathrm{L}$ with a range of $14.18-206.23 \mathrm{mg} / \mathrm{L}$. The mean value of $\mathrm{Mg}^{2+}$ is recorded as $23.05 \pm 29.60 \mathrm{mg} / \mathrm{L}$, whereas the values range between 0.26 and $262.68 \mathrm{mg} / \mathrm{L}$. In addition, the least abundant major element of the study area is $\mathrm{K}^{+}$, and the mean value of the $\mathrm{K}^{+}$was recorded as $2.11 \pm 1.82 \mathrm{mg} / \mathrm{L}$, the values ranging between 0.21 and $11.56 \mathrm{mg} / \mathrm{L}$.

As shown in Table 2, the trend of the distribution of trace elements in the groundwater samples is $\mathrm{Fe}>\mathrm{Mn}>\mathrm{Zn}>\mathrm{Al}>\mathrm{Cu}>\mathrm{Ni}>\mathrm{Pb}>\mathrm{Cr}>\mathrm{Co}>\mathrm{As}>\mathrm{Cd}$. However, none of the above trace elements exceed the permissible levels recommended by the drinking water guidelines by SLS 614:2013, and thus, the effect of these trace elements on the overall quality of the groundwater is expected to be insignificant.

\section{Geochemical Risk Factors Associated With CKDu}

The binary logistic regression analysis was conducted to assess whether the 16 predictor variables $(\mathrm{pH}, \mathrm{EC}, \mathrm{Res}, \mathrm{NaCl}, \mathrm{DO}$, hardness, $\mathrm{HCO}_{3}^{-}, \mathrm{Cl}^{-}, \mathrm{F}^{-}, \mathrm{NO}_{3}^{-}, \mathrm{PO}_{4}^{3-}, \mathrm{SO}_{4}^{2-}, \mathrm{Na}^{+}, \mathrm{Mg}^{2+}$, $\mathrm{K}^{+}$, and $\mathrm{Ca}^{2+}$ ) are significant risk factors causing $\mathrm{CKDu}$ in the UP. According to the best fit model, eight of the 16 variables $\left(\mathrm{pH}, \mathrm{NaCl}, \mathrm{PO}_{4}^{3-}, \mathrm{SO}_{4}^{2-}, \mathrm{F}^{-}, \mathrm{Cl}^{-}, \mathrm{HCO}_{3}^{-}\right.$, and hardness) were found to be significant in terms of the prevalence of $\mathrm{CKDu}$ in the study area. Table 3 illustrates the variables of the best fit model, model coefficients (log-odds terms), and their significance levels. Table 4 shows the adjusted association of geochemical parameters of groundwater with the prevalence of CKDu. After adjustment for confounding, it is revealed that the $\mathrm{PO}_{4}^{3-}$ level of the groundwater is associated with the prevalence of $\mathrm{CKDu}$ in the study area with an odds ratio of 2.8360 (95\% CI = 1.6725-4.8089). Similarly, the $\mathrm{F}^{-}$has a significant impact on the prevalence of CKDu with an odds ratio of 2.1493 (95\% CI = 1.1804-3.9138). Alternatively, the results indicated that, in each unit increase in $\mathrm{PO}_{4}^{3-}$, the odds of developing $\mathrm{CKDu}$ increases by $\sim 184 \%$, whereas in each unit increase in $\mathrm{F}^{-}$, the odds of developing $\mathrm{CKDu}$ increases by $\sim 115 \%$. Therefore, this suggests that $\mathrm{PO}_{4}^{3-}$ and $\mathrm{F}^{-}$of the groundwater might be major risk factors for the prevalence of CKDu in the UP, Sri Lanka.

\section{Fluoride as a Risk Factor for CKDu}

As explained by Ayoob and Gupta (2006), around 200 million people from 25 countries have confronted fluoride-related health issues due to high $\mathrm{F}^{-}$groundwater with fluoride, becoming one of the most significant toxicological environmental hazards globally. However, $\mathrm{F}^{-}$in groundwater could be considered as a blessing or a hazard depending on the $\mathrm{F}^{-}$concentrations in the groundwater $(\mathrm{WHO}, 1984)$. When the $\mathrm{F}^{-}$concentration of the groundwater ranges between 0.50 and $1.50 \mathrm{mg} / \mathrm{L}$, it provides beneficial effects with human teeth, but, with the lower concentrations $(<0.50 \mathrm{mg} / \mathrm{L})$ of $\mathrm{F}^{-}$in groundwater, 
TABLE 3 | The summary of the best-fitted model.

\begin{tabular}{lcccc}
\hline & Estimate & Std. error & z value & $\operatorname{Pr}(>|\mathbf{z}|)$ \\
\hline (Intercept) & 4.3757 & 2.3584 & 1.8550 & $0.0635^{\mathrm{d}}$ \\
$\mathrm{pH}$ & -0.8045 & 0.3555 & -2.2630 & $0.0236^{\mathrm{c}}$ \\
$\mathrm{NaCl}$ & 0.0030 & 0.0012 & 2.7980 & $0.0051^{\mathrm{b}}$ \\
Phosphate & 1.0424 & 0.2695 & 3.8690 & $0.0001^{\mathrm{a}}$ \\
Sulfate & -0.0179 & 0.0072 & -2.4960 & $0.0125^{\mathrm{c}}$ \\
Fluoride & 0.7652 & 0.3058 & 2.5020 & $0.0123^{\mathrm{c}}$ \\
Chloride & -0.0078 & 0.0046 & -1.6800 & $0.0929^{\mathrm{d}}$ \\
Bicarbonate & -0.0082 & 0.0029 & -2.7550 & $0.0058^{\mathrm{b}}$ \\
Hardness & 0.0034 & 0.0021 & 1.6160 & $0.1061^{\mathrm{e}}$ \\
\hline
\end{tabular}

Significance codes: ${ }^{a} P<0.00,{ }^{b} P<0.001,{ }^{c} P<0.01,{ }^{d} P<0.05$, and ${ }^{e} P<0.1$.

TABLE 4 | Odds ratios, 95\% confidence interval, and $p$-values of model variables.

\begin{tabular}{lccc}
\hline Variable & $\begin{array}{c}\text { Odds } \\
\text { ratio }\end{array}$ & $\begin{array}{c}\text { 95\% Confidence interval } \\
\text { of odds ratios }\end{array}$ & $\begin{array}{c}\boldsymbol{p} \text {-value } \\
\text { (LR test) }\end{array}$ \\
\hline Phosphate & 2.8360 & $(1.6725,4.8089)$ & $<0.0010$ \\
Fluoride & 2.1493 & $(1.1804,3.9138)$ & 0.0087 \\
Hardness & 1.0034 & $(0.9993,1.0075)$ & 0.0970 \\
$\mathrm{NaCl}$ & 1.0033 & $(1.0010,1.0057)$ & 0.0011 \\
Chloride & 0.9922 & $(0.9831,1.0013)$ & 0.0872 \\
Bicarbonate & 0.9918 & $(0.9860,0.9976)$ & 0.0025 \\
Sulfate & 0.9822 & $(0.9685,0.9962)$ & 0.0071 \\
Dissolved Oxygen (DO) & 0.9346 & $(0.8797,0.9931)$ & 0.0229 \\
pH & 0.4473 & $(0.2229,0.8978)$ & 0.0123 \\
\hline
\end{tabular}

it strengthens the risk of tooth decay, and the higher concentrations $(>1.50 \mathrm{mg} / \mathrm{L})$ of $\mathrm{F}^{-}$leads to harmful effects on the human body (WHO, 1984). The most found harmful effects of high consumption of fluoride-rich groundwater are fluorosis including dental, skeletal, and non-skeletal fluorosis like neurological complications (Lineswara, 2003; Indermitte et al., 2007; Shailaja and Johnson, 2007). Furthermore, as explained by Mesdaghinia et al. (2010), other health issues that occur due to the consumption of high $\mathrm{F}^{-}$are recorded as CKDs. However, $\mathrm{F}^{-}$concentrations range between 0.02 and $5.65 \mathrm{mg} / \mathrm{L}$ (mean 0.97 $\pm 0.83 \mathrm{mg} / \mathrm{L}$ ), with $27 \%$ of the samples exceeding the Sri Lanka standard for potable water (SLS 614: 2013) limit, whereas 35\% of groundwater samples are below the $0.5 \mathrm{mg} / \mathrm{L}$, indicating that the $\mathrm{F}^{-}$rich water samples are not suited for drinking purposes in the UP. Only $35 \%$ of the samples are suitable and beneficial to human health according to Sri Lankan standards 614:2013 for potable water (Table 5).

In the Badulla district (rainfall received from four seasons), the majority of the farmers are engaged in vegetable farming including potatoes, carrots, beans, leeks, cabbage, green chili, tomatoes, and beetroot. In the Monaragala district (rainfall received from two seasons), paddy and field crops such as maize, cowpea, groundnut, and green grams were grown. Irrigation is largely practiced in the Monaragala district, and it increases the sodicity of the soil. Furthermore, the phosphate fertilizers
TABLE 5 | Suitability of groundwater in terms of $\mathrm{F}^{-}$levels.

\begin{tabular}{lcccc}
\hline $\begin{array}{l}\text { F concentration } \\
\text { (mg/L) }\end{array}$ & $\begin{array}{c}\text { Number of } \\
\text { dug wells }\end{array}$ & $\begin{array}{c}\text { Number of } \\
\text { tube wells }\end{array}$ & $\begin{array}{c}\text { Dug wells } \\
\text { (\%) }\end{array}$ & $\begin{array}{c}\text { Tube wells } \\
\text { (\%) }\end{array}$ \\
\hline$<0.5$ & 63 & 21 & 40 & 31 \\
$0.5<\mathrm{F}<1.5$ & 52 & 27 & 33 & 40.3 \\
$<1.5$ & 42 & 19 & 26.8 & 28.4 \\
Total & 157 & 67 & $\begin{array}{c}67 \% \text { not } \\
\text { suited }\end{array}$ & $\begin{array}{c}59.7 \% \text { not } \\
\text { suited }\end{array}$ \\
\hline
\end{tabular}

used for irrigation purposes are expected to contribute to the high $\mathrm{F}^{-}$concentration in the aquifers. It should be noted that the concentration of $\mathrm{F}^{-}$in groundwater samples (51.5\%) taken from wells in agricultural fields came under the suitable category and $69 \%$ of samples collected from domestic wells (garden dug wells) were also not suitable for drinking. This shows that the contribution by fertilizers used in agriculture did not play a major role in increasing the $\mathrm{F}^{-}$concentration in significant amounts in groundwater. Dharmagunawardhane and Dissanayake (1993) and Young et al. (2011) speculate that the major causative factor for the high $\mathrm{F}^{-}$levels in the dry zone areas of Sri Lanka can be the underlying basement rocks. The UP is composed mainly of metasedimentary and meta-igneous rocks with few granitic intrusions with dominant hornblende- and biotite-bearing migmatites and gneisses (Figure 2, Malaviarachchi et al., 2021). Both hornblende and biotite are hydrous mineral phases that can host $\mathrm{F}^{-}$(Wilson et al., 2013). Thus, basement rocks in the area seem highly favorable subsurface source supplying $\mathrm{F}^{-}$to the groundwater (Figure 2). Although it is not known with certainty that the host rock where rock-water interaction takes place is same as the bedrock exposed where the wells are located, thick rock profiles of hornblende- and biotite-bearing rocks (Figure 2) with low dip angles are very likely to host for the wells.

In addition, because of the existence of fractures in the crystalline bedrock, the deep groundwater has a long residence time in the fractured basement rocks. The area mainly consists of shallow regolith aquifers $(2-10 \mathrm{~m})$ and deep fracture zone aquifers (>30-40 m) (Karunaratne, 2002).

Rao et al. (1993) stated that alkaline waters that contact bedrocks are capable of activating the processes of dissolution of $\mathrm{F}^{-}$in the groundwater and increase the $\mathrm{F}^{-}$concentrations of the groundwater. Saxena and Ahmed (2003) explained that the alkaline nature of the groundwater could increase the $\mathrm{F}^{-}$levels as the alkaline water can mobilize $\mathrm{F}^{-}$from minerals. According to this study, the correlation matrix of the groundwater quality parameters (Figure 3) illustrates that the concentration of $\mathrm{F}^{-}$ increases with $\mathrm{pH}(r=0.1, p$-value $=0.15), \mathrm{HCO}_{3}^{-}(r=0.7$, $p$-value $=0.00), \mathrm{Na}^{+}(r=0.6, p$-value $=0.00), \mathrm{Mg}^{2+}(r=0.4$, $p$-value $=0.00), \mathrm{K}^{+}(r=0.1, p$-value $=0.00)$, and $\mathrm{Ca}^{2+}(r=0.2$, $p$-value $=0.00)$.

Furthermore, Figure 4 shows that the $\mathrm{F}^{-}$is positively correlated with $\mathrm{pH}, \mathrm{HCO}_{3}^{-}$, and total cations $\left(\mathrm{Na}^{+}, \mathrm{Mg}^{2+}\right.$, $\mathrm{K}^{+}$, and $\mathrm{Ca}^{2+}$ ). Overall, high $\mathrm{pH}$, high $\mathrm{HCO}_{3}^{-}$, and high total cations in groundwater lead to leaching of $\mathrm{F}^{-}$increasing the concentration of $\mathrm{F}^{-}$in groundwater. Moreover, $\mathrm{Na}^{+}$and $\mathrm{HCO}_{3}^{-}$ 

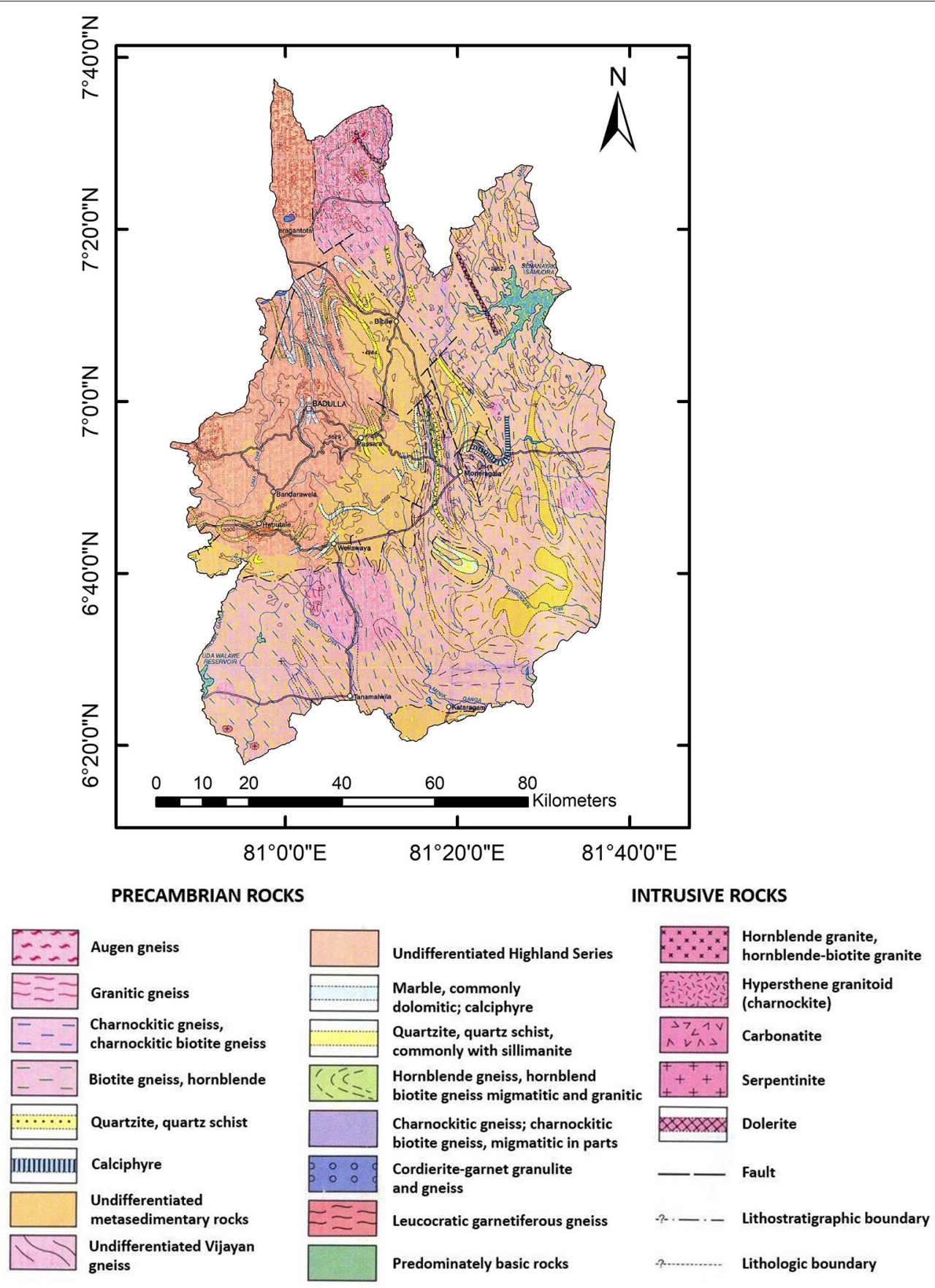

FIGURE 2 | Geology map of the Uva Province (Cooray, 1982).

concentrations are high in the Monaragala district compared with that in Badulla. This indicates that the increase in the concentration of alkalinity $\left(\mathrm{CO}_{3}^{2-}\right.$ and $\left.\mathrm{HCO}_{3}^{-}\right)$, resulting from rock-water interactions, has enhanced the $\mathrm{F}^{-}$concentration. Similar studies have confirmed this finding in other regions of the world (Handa, 1975; Jacks et al., 2005; Guo et al., 2007).

The differences in the interpolated spatial distribution of $\mathrm{F}^{-}$content in the groundwater compared with those in the above two districts are clearly shown in Figure 5. Fluoride can be released from the F-bearing minerals by geochemical reactions in the Monaragala district. Thus, groundwater can be subjected to ion exchange between $\mathrm{Na}^{+}$and $\mathrm{Ca}^{2+}$ in the arid climate resulting in precipitation of calcite by reducing the activity of $\mathrm{Ca}^{2+}$ due to low rainfall, high evapotranspiration, and high salinity (Ramasesha et al., 2020). The $\mathrm{F}^{-}$concentration in groundwater of the Monaragala district varies between 0.02 and $5.65 \mathrm{mg} / \mathrm{L}$, with an average value of $1.16 \mathrm{mg} / \mathrm{L}$. Ninety-two percent of the samples collected in the Monaragala district 


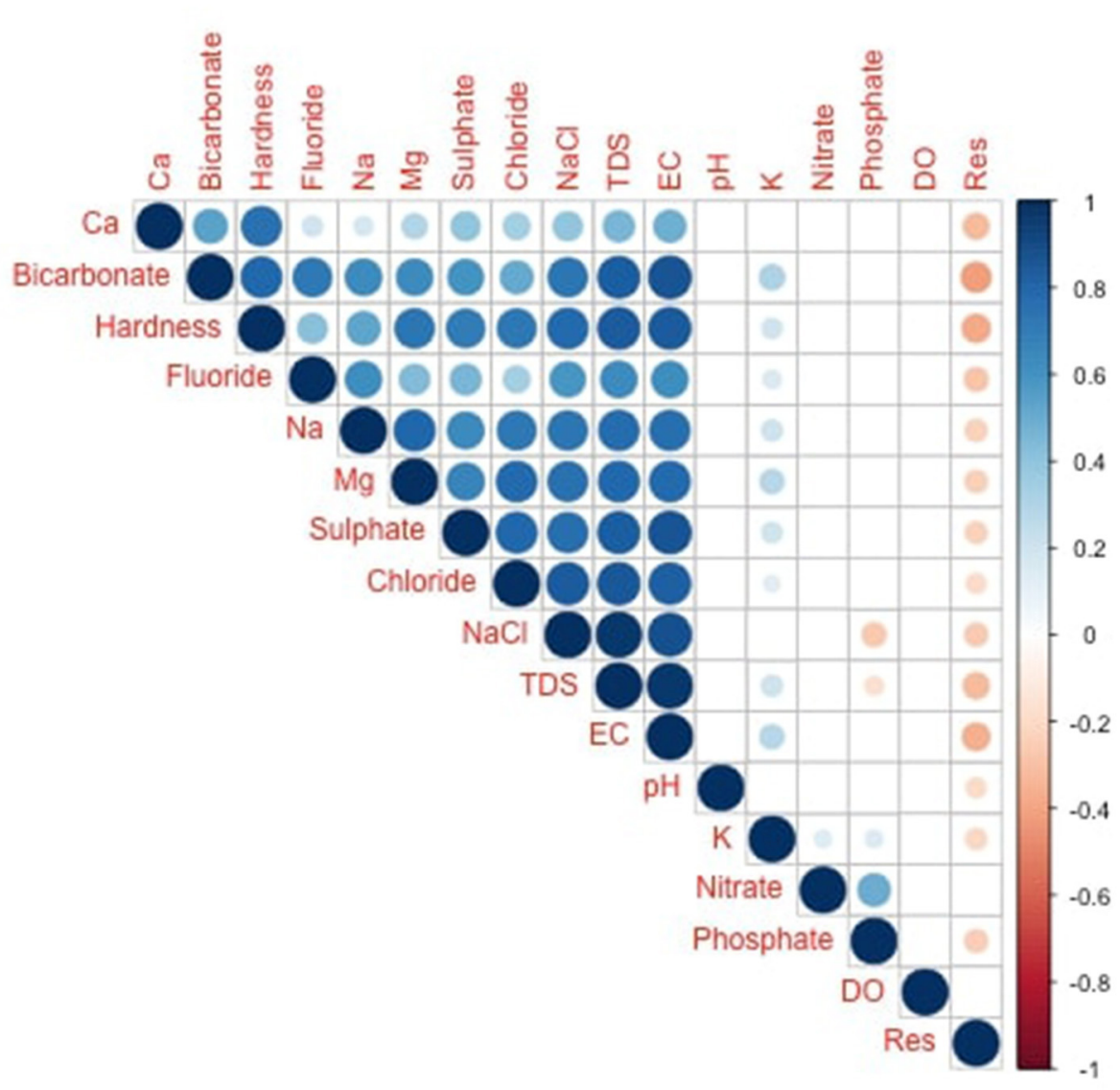

FIGURE 3 | Correlation coefficient matrix of the groundwater quality parameters.

showed an alkaline nature, causing the possible reaction by dissolving $\mathrm{CaF}_{2}$ with alkaline influence on $\mathrm{F}^{-}$concentration as mentioned below (Salve et al., 2008).

$$
\mathrm{CaF}_{2}+2 \mathrm{NaHCO}_{3} \leftarrow \mathrm{CaCO}_{3}+2 \mathrm{Na}+2 \mathrm{~F}^{-}+\mathrm{H}_{2} \mathrm{O}+\mathrm{CO}_{2}
$$

Chandrajith et al. (2011)explained that kidney tabular damages are possible due to the formation of $\mathrm{CaF}_{2}$, which is insoluble in water. Furthermore, they observed that a low $\mathrm{Na} / \mathrm{Ca}$ ratio in groundwater is favorable to form $\mathrm{CaF}_{2}$ complex, which enhances the toxicity of $\mathrm{F}^{-}$ions in the human body and the incidence of $\mathrm{CKDu}$ in endemic $\mathrm{CKDu}$ regions. The spatial distribution map of the $\mathrm{F}^{-}$in UP shows that the areas where high $\mathrm{F}^{-}$varied in the Monaragala district overlapped with high $\mathrm{CKDu}$ prevalent areas, indicating, to some extent, that the $\mathrm{F}^{-}$content of drinking water might contribute to the CKDu (Dissanayake, 1996; Dissanayake and Chandrajith, 2017). The southwest part of the Monaragala district showed a high concentration of $\mathrm{F}^{-}$in groundwater due to weathering of underlying rocks (Fernando and Attanayake, 2017). However, it was clearly understood that the main sources of $\mathrm{F}^{-}$in groundwater are F-bearing minerals such as hornblende-biotite gneisses with certain percentages of $\mathrm{F}^{-}$levels in the Mondragala district (Dharmagunawardhane and Dissanayake, 1993).
It shows that the local modifications of the regional processes over $\mathrm{F}^{-}$distribution appear to have been caused by differences in (a) the abundance of F-bearing minerals present in the host rocks, (b) the degree of rock-weathering and fracturing, and (c) the associated geochemical processes. In this study, $\sim 96 \%$ of the groundwater samples show lower $\mathrm{Na} / \mathrm{Ca}$ ratios $(<10)$, enhancing $\mathrm{F}^{-}$toxicity to people who live in the Monaragala district. Because the Monaragala district receives the total rainfall only from two seasons, the study emphasizes the need to save water by the construction of a number of rainwater harvesting structures to reduce the intensity of higher $\mathrm{F}^{-}$content in the groundwater. This is a simple and environment-friendly approach because all other methods have failed to mitigate the problem. The authorities should supply sufficient safe drinking water for an immediate solution. Thus, this study helps the planners for better management of groundwater quality in similar hydrogeological environmental conditions and other $\mathrm{F}^{-}$affected regions to avoid an intake of groundwater with high $\mathrm{F}^{-}$levels. Because the majority of the samples are scattered into rock weathering zones (Figure 5), it can be inferred that the groundwater $\mathrm{F}^{-}$possibly controlled by chemical weathering of rock-forming minerals. Because of the existence of fractures in the crystalline bedrock, the deep groundwater has a long residence time in the fractured basement rocks. Furthermore, Rao et al. (1993) stated that alkaline waters that contact bedrocks 

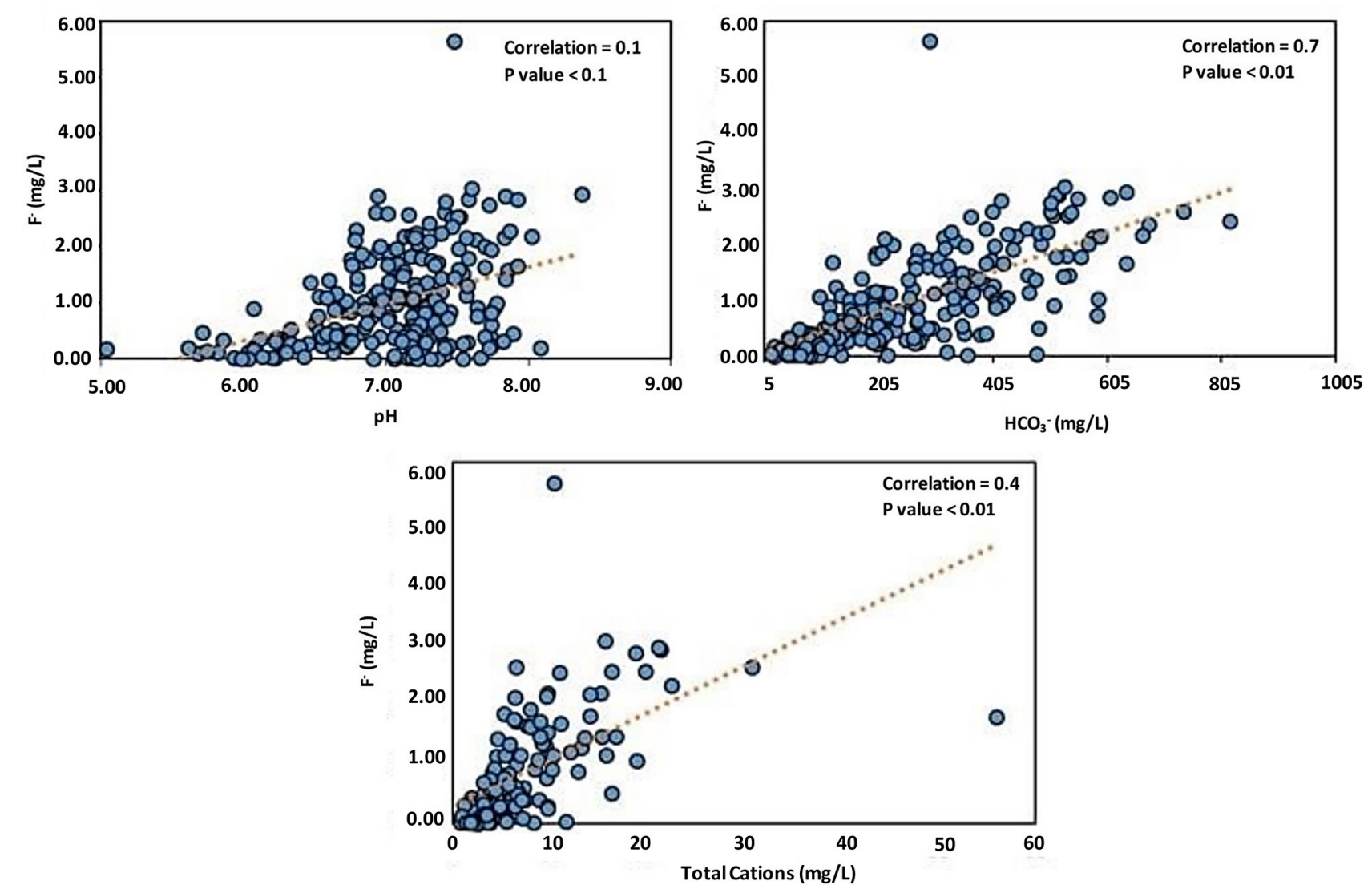

FIGURE 4 | The correlation of $\mathrm{F}^{-}$with $\mathrm{pH}, \mathrm{HCO}_{3}^{-}$, and total cations.

are capable of activating the processes of dissolution of $\mathrm{F}^{-}$in the groundwater.

\section{Phosphate as a Risk Factor for CKDu}

For more than a century, the application of agrochemicals in the agricultural field has been intensively increased (Abdelwaheb et al., 2019). Fertilizers have been recognized as sources of groundwater pollution, especially in $\mathrm{PO}_{4}^{3-}$ (Borggaard et al., 2004; Dissanayake and Chandrajith, 2019), responsible for various health problems such as kidney damage and osteoporosis (Kovesdy and Kalantar-Zadeh, 2008). Generally, $\mathrm{PO}_{4}^{3-}$ was not considered to be a significant problem in groundwater because it is not very mobile in soils or sediments. However, when the soil and subsoil are shallow, $\mathrm{PO}_{4}^{3-}$ tends to enter groundwater in significant quantities, adding more nutrients to groundwater. The threshold value for groundwater $\mathrm{PO}_{4}^{3-}$ concentration of 0.03 $\mathrm{mg} / \mathrm{L}$ is cited in the Phosphate Regulations. Accordingly, only one sample had less than the threshold value, and others exceeded the level, proving that groundwater wells are contaminated because of high $\mathrm{PO}_{4}^{3-}$ concentrations. During the rainy season, it was observed that there was a substantial increase of $\mathrm{PO}_{4}^{3-}$ contents in several unprotected dug wells in the study area where the groundwater table is very shallow. However, higher $\mathrm{PO}_{4}^{3-}$ levels in the samples were recorded from some unprotected dug wells in home gardens, proving that the drinking water wells are largely contaminated by $\mathrm{PO}_{4}^{3-}$ ions. Furthermore, as explained by Rao and Prasad (1997), the groundwater $\mathrm{PO}_{4}^{3-}$ level might be affected because of the geological sources, viz., apatite that contains both $\mathrm{F}^{-}$and $\mathrm{PO}_{4}^{3-}$. In the study area, because there is no strong positive correlation recorded among $\mathrm{PO}_{4}^{3-}, \mathrm{F}^{-}$, and $\mathrm{Cl}^{-}$, it can be inferred that the increased phosphate levels of the study area are caused by fertilizer application rather than from geological sources. The interpolated spatial distribution of the $\mathrm{PO}_{4}^{3-}$ concentrations is shown in Figure 5. However, kidneys are the major regulatory organ of the phosphate balance in the human body (Nadkarni and Uribarri, 2014), and higher serum phosphate concentrations may be associated with incremental death risk of patients with kidney disease who undergo long term hemodialysis (Kestenbaum et al., 2005; Kovesdy and KalantarZadeh, 2008). Furthermore, it has been recognized that higher $\mathrm{PO}_{4}^{3-}$ levels may increase other adverse health outcomes of patients with kidney disease (Ix et al., 2014). Thus, as explained by Calvo et al. (2019), to slow down and prevent the progression of $\mathrm{CKD}$, the intake of $\mathrm{PO}_{4}^{3-}$ should be carefully managed. Thus, the consumption of groundwater with a high level of $\mathrm{PO}_{4}^{3-}$ might be associated with $\mathrm{CKDu}$ in the study area. Moreover, as explained by Shutto et al. (2013), patients with CKD who undergo hemodialysis are not sufficiently aware of the concealed source of $\mathrm{PO}_{4}^{3-}$ in their diet. This needs greater awareness among patients with kidney disease. 


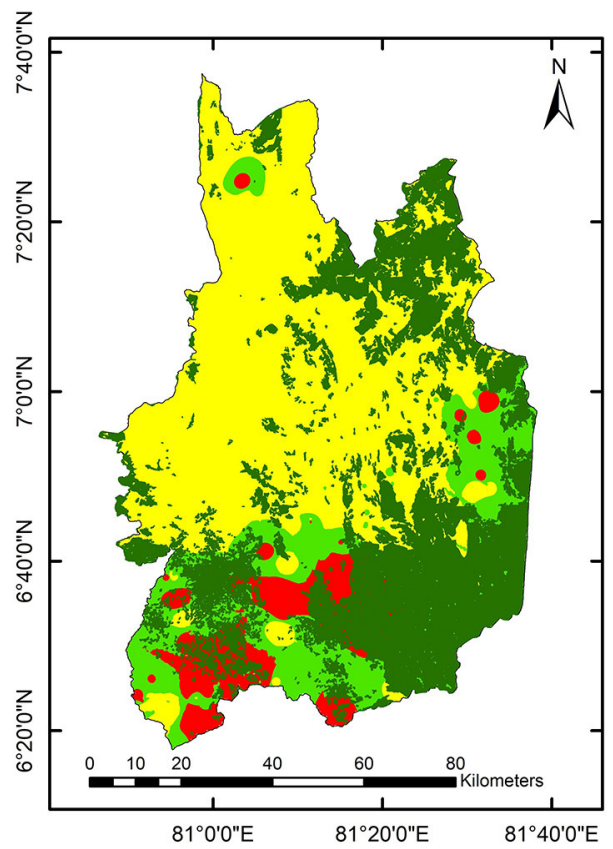

Fluoride (mg/L)

Below desirable limit $(<1.00)$

Suitable (1.00 - 1.50)

Unsuitable $(1.50<)$

Natural Forests

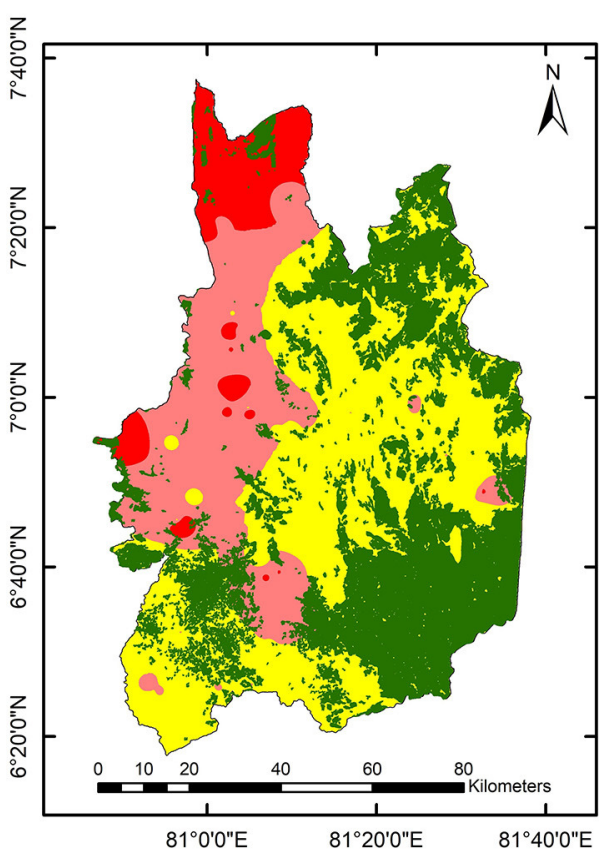

Phosphate (mg/L)

Less Contaminated $(<1.00)$

Contaminated $(1.00-2.00)$

Unsuitable $(2.00<)$

Natural Forests

FIGURE 5 | Maps showing the spatial distribution of $\mathrm{F}^{-}$and $\mathrm{PO}_{4}^{-3}$ in the study area.

\section{Implications for Biomineralization in Kidney Tubules}

The geochemistry of groundwater with high concentrations of $\mathrm{Ca}^{2+}, \mathrm{Mg}^{2+}, \mathrm{F}^{-}$, and $\mathrm{PO}_{4}^{3-}$, as stated by Dissanayake and Chandrajith (2019), is conducive for the biomineralization of calcium phosphates, either as hydroxyapatite or fluorapatite in addition to other forms of calcium phosphates as mixtures. In view of the observations made in this study, the high ionicity of the groundwater may result in significant biomineralization, which will almost certainly have an impact on the incidence of CKDu. The descending loop of Henle in the tubule is very often the site of such mineral deposition, because of an increase in plasma phosphate. A decrease in phosphate fractional readsorption in the proximal tubule (Robertson, 2015) is also a noteworthy factor.

Wimalawansa and Dissanayake (2020) also proposed that $\mathrm{CKDu}$ could be caused by the formation of nanotubes and nanocrystals in renal tubules. They were of the view that, apart from calcium oxalate, apatite minerals with varying compositions may be found within renal tubules, causing interstitial fibrosis, as noted earlier by Ho et al. (2018). The hydrogeochemistry of fluoride is particularly important because fluoride is highly amenable to phosphate crystal formation. Furthermore, as shown by tooth enamel formation, the hardness of fluorapatite is high with obvious implications on renal tubular plugging.
It is of extreme importance to note that the people, who are $\mathrm{CKDu}$ prone, in the dry zone of Sri Lanka, drink water with high concentrations of ions in the water. This, in turn, is highly conducive to the formation of phosphate nanocrystals in kidney tubules, which will cause plugging. The reason why this is so relevant to Sri Lanka is that there had been no studies on this aspect in Sri Lanka, and detailed electron microscopic studies may ultimately reveal the importance of biomineralization on the initiation of CKDu. It is therefore proposed that a major study on nanocrystallization of kidney tubules from Sri Lankan patients with CKDu should be undertaken using electron microscopy. The relevance of such a study is that it will have a major impact on water quality and health in tropical countries, mainly in the equatorial belt.

\section{CONCLUSIONS}

In this cross-sectional study, the groundwater quality status of the UP of Sri Lanka was comprehensively investigated, and the relationships among groundwater quality parameters and the $\mathrm{CKDu}$ were investigated on the basis of a logistic regression model by analyzing odds ratios. According to the best-fit model, $\mathrm{F}^{-}$and $\mathrm{PO}_{4}^{3-}$ levels of the groundwater were found to be the geochemical risk factors that were significantly associated with the progression of $\mathrm{CKDu}$ in the study area. Furthermore, it was 
shown that geochemical processes such as dissolution of bedrocks are the causative phenomenon of the enhancement of $\mathrm{F}^{-}$levels in the groundwater sources of the study area than the effects of the application of agrochemicals. Moreover, it has been observed that the $\mathrm{PO}_{4}^{3-}$ concentrations of the groundwater possibly increase due to the intensive application of agrochemicals. The relatively high concentrations of $\mathrm{F}^{-}, \mathrm{Ca}^{2+}$, and $\mathrm{PO}_{4}^{3-}$ are highly conducive for the formation of calcium phosphates, mainly in the form of apatite as biominerals in the renal tubules. The plugging of the tubules may, in turn, lead to $\mathrm{CKDu}$. This study emphasizes that, to minimize the prevalence of CKDu in the UP of Sri Lanka, effective interventions are needed to be implemented, viz., raising public awareness, enhancing the availability of pure drinking water, and promoting patient activism. The establishment of reverse osmosis (RO) plants is the most common precaution among the suggested short-term measures to control the CKDu.

\section{DATA AVAILABILITY STATEMENT}

The original contributions presented in the study are included in the article/supplementary material, further inquiries can be directed to the corresponding author/s.

\section{REFERENCES}

Abdelwaheb, M., Jebali, K., Dhaouadi, H., and Dridi-Dhaouadi, S. (2019). Adsorption of nitrate, phosphate, nickel and lead on soils: risk of groundwater contamination. Ecotoxicol. Environ. Saf. 179, 182-187. doi: 10.1016/j.ecoenv.2019.04.040

Abeysekara, T. (2015). "Chronic kidney disease of uncertain etiology (CKDu) - causes, consequences and remedies," in International Conference of Sabaragamuwa University of Sri Lanka (ICSUSL) (Belihuloya).

APHA (2005). Standard Methods for the Examination of Water and Wastewater. Washington, DC: APHA-AWWA-WPCF.

Athuraliya, N. T. C., Abeysekera, D. T. D. J., Priyanie, H., Amerasinghe, R. K., Bandara, P. et al. (2011). Uncertain etiologies of proteinuric-chronic kidney disease in rural Sri Lanka. Kidney Int. 80, 1212-1221. doi: 10.1038/ki.2011.258

Athuraliya, T. N. C., Abeysekera, D. T. D. J., Amerasinghe, P. H., Kumarasiri, P. V. R., and Dissanayake, V. (2009). Prevalence of chronic kidney disease in two tertiary care hospitals: high proportion of cases with uncertain aetiology. Ceylon Med. J. 54, 23-25. doi: 10.4038/cmj.v54i1.471

Ayoob, S., and Gupta, A. K. (2006). Fluoride in drinking water: a review on the status and stress effects. Crit. Rev. Environ. Sci. Technol. 36, 433-487. doi: 10.1080/10643380600678112

Bandara, J. M. R. S., Senevirathna, D. M. A. N., Dasanayake, D. M. R. S. B., Herath, V., Bandara, J. M. R. P., Abeysekara, T., et al. (2008). Chronic renal failure among farm families in cascade irrigation systems in Sri Lanka associated with elevated dietary cadmium levels in rice and freshwater fish (Tilapia). Environ. Geochem. Health. 30, 465-478. doi: 10.1007/s10653-007-9129-6

Bandara, J. M. R. S., Wijewardena, H. V. P., Liyanege, J., Upul, M. A., and Bandara, J. M. U. A. (2010). Chronic renal failure in Sri Lanka caused by elevated dietary cadmium: Trojan horse of the green revolution. Toxicol. Lett. 198, 33-39. doi: 10.1016/j.toxlet.2010.04.016

Borggaard, O. K., Szilas, C., Gimsing, A. L., and Rasmussen, L. H. (2004). Estimation of soil phosphate adsorption capacity by means of a pedotransfer function. Geoderma 118, 55-61. doi: 10.1016/s0016-7061(03)00183-6

Calvo, M. S., Sherman, R. A., and Uribarri, J. (2019). Dietary phosphate and the forgotten kidney patient: a critical need for FDA regulatory action. Am. J. Kidney Dis. 73, 542-551. doi: 10.1053/j.ajkd.2018.11.004

Chandrajith, R., Dissanayake, C. B., Ariyarathna, T., Herath, H. M. J. M. K., and Padmasiri, J. P. (2011). Dose-dependent $\mathrm{Na}$ and $\mathrm{Ca}$ in fluoride-rich drinking

\section{AUTHOR CONTRIBUTIONS}

SG, LR, EU, and CD: study conception, design, and critical revision. IP, WU, and $\mathrm{HH}$ : acquisition of data, analysis, interpretation of data, and drafting of manuscript. All authors contributed to the article and approved the submitted version.

\section{FUNDING}

This research was funded by the World Bank under the Accelerating Higher Education Expansion and Development grant number (AHEAD/DOR/STEM/33).

\section{ACKNOWLEDGMENTS}

The authors would like to acknowledge the World Bank for funding Accelerating Higher Education Expansion and Development project under the grant number (AHEAD/DOR/STEM/33). Furthermore, the authors would like to thank Sabaragamuwa University of Sri Lanka and the University of Peradeniya for providing advanced laboratory facilities to carry out this research.

water-another major cause of chronic renal failure in tropical arid regions. Sci. Total Environ. 409, 671-675. doi: 10.1016/j.scitotenv.2010.10.046

Chandrajith, R., Padmasiri, J. P., Dissanayake, C. B., and Prematilaka, K. M. (2012). Spatial distribution of fluoride in groundwater of Sri Lanka. J. Natl. Sci. Found. 40, 303-309. doi: 10.4038/jnsfsr.v40i4.5044

Chaurasia, A. K., Pandey, H. K., Tiwari, S. K., Prakash, R., Pandey, P., and Ram, A. (2018). Groundwater quality assessment using water quality index (WQI) in parts of Varanasi district, Uttar Pradesh, India. J. Geol. Soc. India 92, 76-82. doi: 10.1007/s12594-018-0955-1

Cooray, P. G. (1982). Geological Map of Sri Lanka. King Abdul Aziz University, Jiddah, Kingdom of Saudi Arabia.

Cooray, P. G. (1994). The Precambrian of Sri Lanka: a historical review. Precambrian Res. 66, 3-18.

Coutinho, L., Scazufca, M., and Menezes, P. R. (2008). Methods for estimating prevalence ratios in cross-sectional studies. Rev. Saude Publ. 42, 992-998. doi: 10.1590/s0034-89102008000600003

de Queiroz Mello, F. C., do Valle Bastos, L. G., Soares, S. L. M., Rezende, V. M., Conde, M. B., Chaisson, R. E., et al. (2006). Predicting smear negative pulmonary tuberculosis with classification trees and logistic regression: a cross-sectional study. BMC Public Health 6:43. doi: 10.1186/1471-24 58-6-43

Dharmagunawardhane, H., and Dissanayake, C. B. (1993). Fluoride problems in Sri Lanka. Environ. Manage. Health. 4, 9-16. doi: 10.1108/09566169310033422

Diaz-Quijano, F. A. (2012). A simple method for estimating relative risk using logistic regression. BMC Med. Res. Methodol. 12, 14. doi: 10.1186/1471-2288-12-14

Dissanayake, C. B. (1996). Water quality and dental health in the Dry Zone of Sri Lanka. Geol. Soc. Lond. Spec. Publ. 113, 131-140. doi: 10.1144/gsl.sp.1996.113.01.10

Dissanayake, C. B. (2005). Water quality in the dry zone of Sri Lankasome interesting health aspects. J. Natl. Sci. Found. 33, 161-168. doi: 10.4038/jnsfsr.v33i3.2322

Dissanayake, C. B., and Chandrajith, R. (2017). Groundwater fluoride as a geochemical marker in the etiology of chronic kidney disease of unknown origin in Sri Lanka. Ceylon J. Sci. 46, 3-12. doi: 10.4038/cjs.v46i2. 7425

Dissanayake, C. B., and Chandrajith, R. (2019). Fluoride and hardness in groundwater of tropical regions review of recent evidence indicating tissue 
cacification and calcium phosphate nanopaticle formation in kidney tubules. Ceylon J. Sci. 28, 197-207. doi: 10.4038/cjs.v48i3.7643

Fernando, G., and Attanayake, D. (2017). "Possible causative factors for dental fluorosis in the Monaragala District," in Research Congress of Postgraduate Institute of Science, University of Peradeniya, Sri Lanka (Peradeniya). Available online at: http://repository.ou.ac.lk/handle/94ousl/413

Fernando, I., Ranasinghe, D., Udayakantha, P., and Bandara, W. (2016). "Investigation of multiple drivers and their impact on chronic kidney disease unidentified-a case study in Padaviya Divisional Secretariat, Sri Lanka," in International Forestry and Environment Symposium, University of Sri Jayewardenepura, Sri Lanka (Sri Jayewardenepura).

Gunatilake, S. K., and Iwao, Y. (2009). Geoenvironmental assessment for nitrate pollution of surface and groundwater by fertilization (a study in Shiroishi Plain, Japan). Int. J. Civil Environ. Eng. 9, 12-19.

Gunatilake, S. K., and Iwao, Y. (2010). A comparison of nitrate distribution in shallow groundwater of two agricultural areas in Sri Lanka and in Japan. Sabaragamuwa Univ. J. 9, 81-95. doi: 10.4038/suslj.v9i1.3736

Gunatilake, S. K., Samaratunga, S. S., and Rubasinghe, R. T. (2014). Chronic kidney disease (CKD) in Sri Lanka-current research evidence justification: a review. Sabaragamuwa Univ. J. 13, 31-58. doi: 10.4038/suslj.v13i2.7680

Guo, Q., Wang, Y., Ma, T., and Ma, R. (2007). Geochemical processes controlling the elevated fluoride concentrations in groundwaters of the Taiyuan Basin, Northern China. J. Geochem. Explor., 93, 1-12. doi: 10.1016/j.gexplo.2006.07.001

Handa, B. K. (1975). Geochemistry and genesis of fluoridecontaining ground waters in India. Groundwater 13, 275-281. doi: 10.1111/j.1745-6584.1975.tb03086.x

Ho, S. P., Chen, L., Allen, F. I., Hsi, R. S., Shimotake, A. R., Wiener, S. V., et al. (2018). Architecture-guided fluid flow directs renal biomineralization. Sci.Rep. 21:8. doi: $10.1038 /$ s41598-018-30717-x

Ileperuma, O., Dharmagunawardhane, H., and Herath, K. (2009). Dissolution of aluminium from sub-standard utensils under high fluoride stress: a possible risk factor for chronic renal failure in the North-Central Province. J. Natl. Sci. Found. 37, 219-222. doi: 10.4038/jnsfsr.v37i3.1217

Indermitte, E., Karro, E., and Saavaa, A. (2007). Tap water fluoride levels in Estonia. Fluoride 40, 244-247.

Ix, J. H., Anderson, C. A., Smits, G., Persky, M. S., and Block, G. A. (2014). Effect of dietary phosphate intake on the circadian rhythm of serum phosphate concentrations in chronic kidney disease: a crossover study. Am. J. Clin. Nutr. 100, 1392-1397. doi: 10.3945/ajcn.114.085498

Jacks, G., Bhattacharya, P., Chaudhary, V., and Singh, K. P. (2005). Controls on the genesis of some high-fluoride groundwaters in India. Appl. Geochem. 20, 221-228. doi: 10.1016/j.apgeochem.2004.07.002

Jayasekara, K. B., Dissanayake, D. M., Sivakanesan, R., Ranasinghe, A., Karunarathna, R. H., and Kumara, G. W. G. P. (2015). Epidemiology of chronic kidney disease, with special emphasis on chronic kidney disease of uncertain etiology, in the north central region of Sri Lanka. J. Epidemiol. 25, 275-280. doi: 10.2188/jea.je20140074

Jayasumana, C., Paranagama, P., Agampodi, S., Wijewardane, C., Gunatilake, S., and Siribaddana, S. (2015). Drinking well water and occupational exposure to Herbicides is associated with chronic kidney disease, in Padavi-Sripura, Sri Lanka. Environ. Health 14:6. doi: 10.1186/1476-069x-14-6

Jayasumana, C., Paranagama, P. A., Amarasinghe, M. D., Wijewardane, K. M. R. C., Dahanayake, K. S., Fonseka, S. I., et al. (2013). Possible link of chronic arsenic toxicity with chronic kidney disease of unknown etiology in Sri Lanka. J. Nat. Sci. Res. 3, 64-73.

Jayatilake, N., Mendis, S., Maheepala, P., and Mehta, F. R. (2013). Chronic kidney disease of uncertain aetiology: prevalence and causative factors in a developing country. BMC Nephrol. 14:180. doi: 10.1186/1471-2369-14-180

Karunaratne, R. N. (2002). "Groundwater development through introduction of agro-wells and micro-irrigation in Sri Lanka," in Symposium on Use of Groundwater for Agriculture in Sri Lanka. Post Graduate Institute of Agriculture (Peradeniya).

Kestenbaum, B., Sampson, J. N., Rudser, K. D., Patterson, D. J., Seliger, S. L., Young, B., et al. (2005). Serum phosphate levels and mortality risk among people with chronic kidney disease. J. Am. Soc. Nephrol. 16, 520-528. doi: $10.1681 /$ asn.2004070602
Ketata,. M., Gueddari, M., and Bouhlila, R. (2012). Use of geographical information system and water quality index to assess groundwater quality in El Khairat deep aquifer (Enfidha, Central East Tunisia). Arab. J. Geosci. 5, 1379-1390. doi: 10.1007/s12517-011-0292-9

Kleinbaum, D. G., Dietz, K., Gail, M., Klein, M., and Klein, M. (2002). Logistic Regression. New York, NY: Springer-Verlag. p. 536.

Kovesdy, C. P., and Kalantar-Zadeh, K. (2008). Bone and mineral disorders in predialysis CKD. J. Nephrol. Urol. 40, 427-440. doi: 10.1007/s11255-008-9346-7

Kumaresan, J., and Seneviratne, R. (2017). Beginning of a journey: unraveling the mystery of chronic kidney disease of unknown aetiology (CKDu) in Sri Lanka. Global. Health. 13, 43. doi: 10.1186/s12992-017-0268-y

Levine, K. E., Redmon, J. H., Elledge, M. F., Wanigasuriya, K. P., Smith, K., Munoz, B., et al. (2016). Quest to identify geochemical risk factors associated with chronic kidney disease of unknown etiology (CKDu) in an endemic region of Sri Lanka-a multimedia laboratory analysis of biological, food, and environmental samples. Environ. Monit. Assess. 188, 548. doi: 10.1007/s10661-016-5524-8

Lineswara, R. S. (2003). Fluoride toxicity in Raptadu mandal, Anantapura district, Andhra Pradesh. Curr. Sci. 3,329-334.

Malaviarachchi, S. P., Satish-Kumar, M., and Takahashi, T. (2021). New Sr-Nd isotope data record juvenile and ancient crust-mantle melt interactions in the vijayan complex, Sri Lanka. J. Geol. 129, 233-253.. doi: 10.1086/714172

Martuzzi, M., and Elliott, P. (1998). Estimating the incidence rate ratio in cross-sectional studies using a simple alternative to logistic regression. Ann. Epidemiol. 8, 52-55. doi: 10.1016/s1047-2797(97)00106-3

Mesdaghinia, A., Vaghefi, K. A., Montazeri, A., Mohebbi, M. R., and Saeedi, R. (2010). Monitoring of fluoride in groundwater resources of Iran. Bull. Environ. Contam. Toxicol. 84, 432-437. doi: 10.1007/s00128-010-9950-y

Murphy, J., and Riley, J. P. (1962). A modified single solution method for the determination of phosphate in natural waters. Anal. Chim. Acta 27, 31-36. doi: 10.1016/s0003-2670(00)88444-5

Murray, C. J., Lopez, A. D., Mathers, C. D., and Stein, C. (2001). The Global Burden of Disease 2000 Project: Aims, Methods and Data Sources. Geneva: World Health Organization 36, 1-57.

Nadkarni, G. N., and Uribarri, J. (2014). Phosphorus and the kidney: what is known and what is needed. Adv. Nutr. 5, 98-103. doi: 10.3945/an.113.004655

Nelson, D. (2002). Natural Variations in the Composition of Groundwater. Drinking Water Program, Oregon Department of Human Services, Springfield, Oregon.

Noble, A., Amerasinghe, P., Manthrithilake, H., and Arasalingam, S. (2014). Review of Literature on Chronic Kidney Disease of Unknown Etiology (CKDu) in Sri Lanka, Vol. 158. IWMI, Sri Lanka.

Pius, A., Jerome, C., and Sharma, N. (2012). Evaluation of groundwater quality in and around Peenya industrial area of Bangalore, South India using GIS techniques. Environ. Monit. Assess. 184, 4067-4077. doi: 10.1007/s10661-011-2244-y

Piyathilake, I. D. U. H., Sumudumali, R. G. I., Udayakumara, E. P. N., Ranaweera, L. V., Jayawardana, J. M. C. K., and Gunatilake, S. K. (2020). Modeling predictive assessment of soil erosion related hazards at the Uva province in Sri Lanka. Model. Earth. Syst. Environ. 7, 1947-1962. doi: $10.1007 /$ s40808-020-00944-1

Piyathilake, I. D. U. H., Udayakumara, E. P. N., Ranaweera, L. V., and Gunatilake, S. K. (2021). Modeling predictive assessment of carbon storage using InVEST model in Uva province, Sri Lanka. Model. Earth Syst. Environ. 2021, 1-11. doi: 10.1007/s40808-021-01207-3

Pry, J. M., Jackson, W., Rupasinghe, R., Lishanthe, G., Badurdeen, Z., Abeysekara, T., et al. (2019). A pilot study of behavioral, environmental, and occupational risk factors for chronic kidney disease of unknown etiology in Sri Lanka. bioRxiv 837393. doi: 10.1101/837393

Rajapakshe, S. M., Weragoda, S. K., Kawakami, T., and Weerasekara, W. B. M. L. I. (2018). "Study of evidences on chronic kidney disease due to unknown etiology based on environmental, social, economic and health patterns of selected population," in International Conference on Sustainable Built Environment (Singapore: Springer), 99-106. doi: 10.1007/978-981-13-9749-3_9

Ramasesha, C., Nandakumaran, P., and Suresh, S. (2020). "Efficacy of sub-surface dykes as groundwater conservation structures in hard rock terrain of Tamil Nadu, India," in Management of Aquifer Recharge for Sustainability, ed P. J. Dillon (London: CRC Press), 399-404. doi: 10.1201/9781003078838-82 
Rao, N. R., Rao, N., Rao, K. S. P., and Schuiling, R. (1993). Fluorine distribution in waters of Nalgonda district, Andhra Pradesh, India. Environ. Geol. 21, 84-89. doi: 10.1007/bf00775055

Rao, N. S., and Prasad, P. R. (1997). Phosphate pollution in the groundwater of lower Vamsadhara river basin, India. Environ. Geol. 31, 117-122. doi: $10.1007 /$ s002540050170

Ravikumar, P., Somashekar, R., and Angami, M. (2011). Hydrochemistry and evaluation of groundwater suitability for irrigation and drinking purposes in the Markandeya River basin, Belgaum District, Karnataka State, India. Environ. Monit. Assess. 173, 459-487. doi: 10.1007/s10661-010-1399-2

RDA (2017). Initial Environmental Examination of Second Integrated Road Investment Program. Road Development Authority, Ministry of Higher Education and Highways for the Government of Sri Lanka and the Asian Development Bank, Sri Lanka.

Robertson, W. G. (2015). Potential role of fluctuations in the composition of renal tubular fluid through the nephron in the initiation of Randall's plugs and calcium oxalate crystalluria in a computer model of renal function. Urolithiasis 43, 93-107. doi: 10.1007/s00240-014-0737-1

Salve, P., Maurya, A., Kumbhare, P., Ramteke, D., and Wate, S. (2008). Assessment of groundwater quality with respect to fluoride. Bull. Environ. Contam. Toxicol. 81, 289-293. doi: 10.1007/s00128-008-9466-x

Saxena, V., and Ahmed, S. (2003). Inferring the chemical parameters for the dissolution of fluoride in groundwater. Environ. Geol. 43, 731-736. doi: 10.1007/s00254-002-0672-2

Shailaja, K., and Johnson, M. E. C. (2007). Fluorides in groundwater and its impact on health. J. Environ. Biol. 28, 331-332.

Shutto, Y., Shimada, M., Kitajima, M., Yamabe, H., Saitoh, Y., Saitoh,. H., et al. (2013). Inadequate awareness among chronic kidney disease patients regarding food and drinks containing artificially added phosphate. PLOS ONE 8:e78660. doi: 10.1371 /journal.pone.0078660

Steenvoorden, J. (1976). Nitrogen, Phosphate and Biocides in Groundwater as Influenced by Soil Factors and Agriculture, Vol. 97. Institute for Land and Water Management Research.

UPC (2019). Five Year Vision Oriented Integrated Sustainable Development Plan of Uva Province, Sri Lanka.

Wanasinghe, W., Gunarathna, M., Herath, H., and Jayasinghe, G. (2018). Drinking water quality on chronic kidney disease of unknown aetiology (CKDu) in Ulagalla Cascade, Sri Lanka. Sabaragamuwa Univ. J. 16, 17-27. doi: 10.4038/suslj.v16i1.7714

Wanigasuriya, K. (2012). Aetiological factors of chronic kidney disease in the North Central Province of Sri Lanka: a review of evidence to-date. J. Coll. Commun. Phys. Sri Lanka 17, 15-20. doi: 10.4038/jccpsl.v17i1. 4931

Wanigasuriya, K. (2014). Update on uncertain etiology of chronic kidney disease in Sri Lanka's North-Central dry zone. MEDICC Rev. 16, 61-65. doi: $10.37757 / \mathrm{mr} 2014 . v 16 . n 2.10$
Wanigasuriya, K. P., Peiris-John, R. J., and Wickremasinghe, R. (2011). Chronic kidney disease of unknown aetiology in Sri Lanka: is cadmium a likely cause? BMC Nephrol. 12:32. doi: 10.1186/1471-2369-12-32

Wanigasuriya, K. P., Peiris-John, R. J., Wickremasinghe, R., and Hittarage, A. (2007). Chronic renal failure in North Central Province of Sri Lanka: an environmentally induced disease. Trans. R. Soc. Trop. Med. Hyg. 101, 1013-1017. doi: 10.1016/j.trstmh.2007.05.006

WHO (1984). Health Promotion: A Discussion Document on the Concept and Principles: Summary Report of the Working Group on Concept and Principles of Health Promotion, Copenhagen: WHO Regional Office for Europe.

Wilson, M., Deer, W., Howie, R., and Zussman, J. (2013). Rock-Forming Minerals, Vol. 3C, Sheet Silicates: Clay Minerals. London: Geological Society.

Wimalawansa, S. J. (2016). The role of ions, heavy metals, fluoride, and agrochemicals: critical evaluation of potential aetiological factors of chronic kidney disease of multifactorial origin (CKDmfo/CKDu) and recommendations for its eradication. Environ. Geochem. Health. 38, 639-678. doi: 10.1007/s10653-015-9768-y

Wimalawansa, S. J., and Dissanayake, C. B. (2020). Factors affecting the environmentally induced chronic kidney disease of unknown aetiology in dry zonal regions in tropical countries - novel findings. Environments 7, 1-26. doi: 10.3390/environments7010002

Wu, M.-Y., and Wu, M.-S. (2019). "Pathophysiology of leptospirosis kidney disease," in Leptospirosis and the Kidney, Vol 7, eds C.-W. Yang, M.-J. Pan, and H.-Y. Yang (Basel: Karger Publishers), 10-19. doi: 10.1159/000500378

Young, S. M., Pitawala, A., and Ishiga, H. (2011). Factors controlling fluoride contents of groundwater in north-central and northwestern Sri Lanka. Environ. Earth. Sci. 63, 1333-1342. doi: 10.1007/s12665-010-0804-z

Conflict of Interest: The authors declare that the research was conducted in the absence of any commercial or financial relationships that could be construed as a potential conflict of interest.

Publisher's Note: All claims expressed in this article are solely those of the authors and do not necessarily represent those of their affiliated organizations, or those of the publisher, the editors and the reviewers. Any product that may be evaluated in this article, or claim that may be made by its manufacturer, is not guaranteed or endorsed by the publisher.

Copyright (C) 2021 Piyathilake, Udeshani, Hapuarachchi, Ranaweera, Udayakumara, Gunatilake and Dissanayake. This is an open-access article distributed under the terms of the Creative Commons Attribution License (CC BY). The use, distribution or reproduction in other forums is permitted, provided the original author(s) and the copyright owner(s) are credited and that the original publication in this journal is cited, in accordance with accepted academic practice. No use, distribution or reproduction is permitted which does not comply with these terms. 